\title{
How Do the Cultural Dimensions of Climate Shape Our Understanding of Climate Change?
}

\author{
Jason Alexandra ${ }^{1,2}$ (D) \\ 1 Alexandra and Associates, 16 Homestead Road Eltham, Melbourne, VIC 3095, Australia; \\ jason@alexandra-consulting.com \\ 2 School of Global, Urban and Social Studies, RMIT University, Melbourne, VIC 3000, Australia
}

check for updates

Citation: Alexandra, J. How Do the Cultural Dimensions of Climate Shape Our Understanding of Climate Change? Climate 2021, 9, 63. https:// doi.org/10.3390/cli9040063

Academic Editors: Steven McNulty and Thomas Beery

Received: 28 February 2021

Accepted: 8 April 2021

Published: 10 April 2021

Publisher's Note: MDPI stays neutral with regard to jurisdictional claims in published maps and institutional affiliations.

Copyright: (C) 2021 by the author. Licensee MDPI, Basel, Switzerland. This article is an open access article distributed under the terms and conditions of the Creative Commons Attribution (CC BY) license (https:// creativecommons.org/licenses/by/ $4.0 /)$.

Abstract: Climatic events express the dynamics of the Earth's oceans and atmosphere, but are profoundly personal and social in their impacts, representation and comprehension. This paper explores how knowledge of the climate has multiple scales and dimensions that intersect in our experience of the climate. The climate is objective and subjective, scientific and cultural, local and global, and personal and political. These divergent dimensions of the climate frame the philosophical and cultural challenges of a dynamic climate. Drawing on research into the adaptation in Australia's Murray Darling Basin, this paper outlines the significance of understanding the cultural dimensions of the changing climate. This paper argues for greater recognition of the ways in which cultures co-create the climate and, therefore, that the climate needs to be recognised as a socio-natural hybrid. Given the climate's hybrid nature, research should aim to integrate our understanding of the social and the natural dimensions of our relationships to a changing climate.

Keywords: critical realism; cultural adaptation; custodial ethics; socio-natural hybrids; knowledge politics; climate subjectivities; climate co-production

\section{Introduction}

Each time we take in information about the weather from forecasts delivered via television, radio, the press, books, posters or the Internet, we are receiving the product of an extraordinary cooperative, international effort to understand the Earth's systems and their dynamics, which frame our understanding of the world [1]. A global network of instrumentation observations, technologies, models, theories, data and communications involving people, technologies, skills and knowhow produce these forecasts, contributing to our comprehension of the planetary systems at the local and global scale [2]. When we use these forecasts to make decisions about our work and life, we are processing and acting on this information, responding to nature (as in natural phenomena) and the culturally constructed system of representing and understanding nature [3]. We are part of enormous cultural and scientific information processing systems that construct the knowing and governing of the climate via technological, scientific and social networks [4].

This paper argues that knowledge of the climate has multiple scales and dimensions. The climate is objective and subjective, scientific and cultural, local and global and personal and political. This paper explores these contextual and cultural dimensions of the climate. It seeks to expand the scope of definitions of 'the climate' and examine some of the philosophical and cultural challenges posed by a dynamic climate. The central idea is that climate change is an objective fact and a subjective reality that frames our understanding and experience of the world.

The question central to this investigation is: how do the cultural dimensions of the climate, including the subjectivities involved, shape our understanding of climate change?

The opening up of debate around these questions is not arguing that climate change is entirely relative, or merely a matter of belief, rather than an objective fact about the Earth's systems changing. Instead, it is querying whether greater recognition of the co-existence 
of subjectivity and objectivity in meaning-making would enhance commitment to actions that build on the scientific understanding of the rapidly changing climate.

This paper builds on the idea that the natural and social worlds coexist and coproduce reality, through forming socio-natural hybrids [5]. These hybrids combine social and natural phenomena. Understanding these hybrids requires bringing together the social and natural sciences. Furthermore, it requires recognising the rituals and culture of science and scientific endeavours that influence society by contributing to the construction of meaning [5]. The global phenomenon of climate change illustrates the complex, evolving nature of these hybrids [6,7]. This paper portrays climate and climate adaptation as socionatural hybrids-those complex systems that link geophysical and socio-political processes in ways which cannot be neatly separated [5,7].

The paper argues that climate science contributes to the cultural construction of meaning around climate issues $[1,7]$ and that understanding of climate science occurs within relational networks that are profoundly social and political [4]. Furthermore, people's understanding of climate change depends on their social networks and contexts $[4,6]$. Theoretical concepts of the climate permeate our cultural understandings and lived experience of the modern world. Therefore, the climatic conditions we understand and experience are culturally co-constructed with the natural phenomena of the weather. How this cultural construction of the climate evolves is a worthy subject of scholarship [1,2,4,7].

Section 2 outlines this paper's origins in research on climate adaptation in Australia's Murray Darling Basin (MDB). It also outlines why critical realism's philosophy offers a framework for integrating the social and natural sciences and accommodating positivist and constructivist perspectives.

Section 3 describes some of the challenges of adaptation in river basins, illustrating this with the MDB example.

Section 4 outlines the main arguments about why the cultural construction of climate needs to be more widely recognised in the scholarship on climate change.

Section 5 offers some tentative conclusions.

\section{Approach and Methods}

\section{Integrating Positivist and Relativists Perspectives}

This paper reflects research into climate adaptation in Australia's MDB [8]. This research focused on the science-policy interface and the politics of governing a large river basin in a dynamic climate regime $[9,10]$. This paper uses examples from the MDB for illustrative purposes, focusing on how climate and climate change manifest in the cultural and socio-political realm.

This paper draws on scholarship on Australia's highly variable and changing climate [11-15]. The extensive international literature on climate adaptation is also used [1,2,16,17].

This examination of cultural dimensions of climate proposes that critical realism offers ways to integrate natural and social science in understanding society [18]. Critical realism is a philosophy of science that recognises the 'real' physical world but proposes that this can only be partially understood and always through cultural prisms within historical contexts [19]. Critical realism, therefore, offers a framework for understanding socio-natural hybrids - such as water and the climate-that incorporates and integrates positivist, relativist and constructivist perspectives [20]. This integration is needed because research into complex sustainability issues, such as climate change, requires understanding many "simultaneously acting and interacting determinates operating at different spatial and temporal scales" [21]. Furthermore, the natural sciences alone are inadequate for dealing with the ways in which issues such as climate change involve interactions between science and the law, politics, the media and popular culture, that together construct meaning $[6,7]$.

Recognition of the climate's cultural dimensions is needed to understand how and why certain understandings, imaginaries, and policy positions become normalised and adopted, producing particular logics and outcomes [22]. Mollinga [22] argues that all understandings of 'reality' are historically and culturally conditioned, but these understandings are 'real' 
because they generate social, political and economic effects. In short, it is necessary to interpret the cultural determinants of our understanding of the world (along with scientific, environmental, political and economic ones) because shifting cultural perspectives and changing values are critical determinants of policy decisions [22]. These shifts occur in societies with different histories, traditions and levels of economic development, which can affect environmental policy development and implementation.

Shifting cultural values are playing out in the many ongoing national and international debates about climate policies [7]. These debates illustrate the emergence of new imaginaries about humans' roles and responsibilities as custodians of the planet and its systems and the ethics involved [7]. The popular metaphor of planetary boundaries, and the grave risk associated with breaching them, is one of these imaginaries [23-25]. The opposing imaginary of limitless growth through open markets within a borderless world is another, which Latour [7] claims is a disembodied, apolitical and dangerous ideal. Both are manifesting in contemporary debates about the politics of climate change.

These kinds of debates play out in countless local and national settings, not just at the international forums seeking multi-lateral agreements. One significant scale is the river basin, where global circulation changes manifest as changing water availability for cities, agriculture, and ecosystems [26]. The following section briefly examines climate adaptation in Australia's MDB.

\section{River Basins and Climate Adaptation-The Case of the MDB}

\subsection{Climate Adaptation in Australia's MDB}

Water is the principal medium expressing climate change's material impacts. Changing precipitation patterns and intensifying droughts and floods have far-reaching social and economic consequences [26-29]. By altering rivers, climate change is affecting billions of people, through disruptions to water, energy and food production systems, with the nexus between these being increasingly recognised $[26,27,30]$. Human activities such as deforestation, industrialization, and urbanization also influence rivers and the climate and together with climate change are factors fundamentally disrupting conventional water resource management [30-33].

This disruption occurs in the MDB-Australia's largest and most economically important river system (Figure 1) —with strong scientific evidence underpinning decades of warnings about drier futures [33-37]. The MDB is a microcosm of many mid-latitude regions' climate adaptation issues [26,33]. With more intense droughts, declining stream flows, less reliable water resources and higher temperatures, significant water resource management adjustments are needed [38]. Australia's national science agency, CSIRO, has repeatedly warned of drier futures [34-36]. Observed warming and drying trends are consistent with the scientific predictions delivered since the 1980s [39]. Record-breaking extremes validate these warnings [37], and the cascading impacts of unprecedented droughts, including massive fish-kills, are intensifying conflicts over water [40].

In 2007, Australia's Commonwealth Government legislated for a MDB Plan that prepares for climate change using the best available science [41]. However, the pressure to adapt to a more dynamic climate regime remains a pressing priority. Water yields from historically reliable catchments are reducing due to rising temperatures, increased evapotranspiration, and lower rainfall [42-44]. There are increasing concerns about freshwater ecosystem conservation [45,46], regional economies [47], and confidence in governments capacity to deliver reforms in the public's interest [48]. Therefore, the MDB provides a practical example of climate adaption politics in a large, economically significant river basin [9]. However, during their implementation, the reforms intended to deal with environmental water needs and climate change became highly contested and conflictual [49]. The result of the planning process was a Basin Plan, which relies on the historical average water resources $[9,41]$ despite consistent scientific predictions about drier futures [33-37]. 


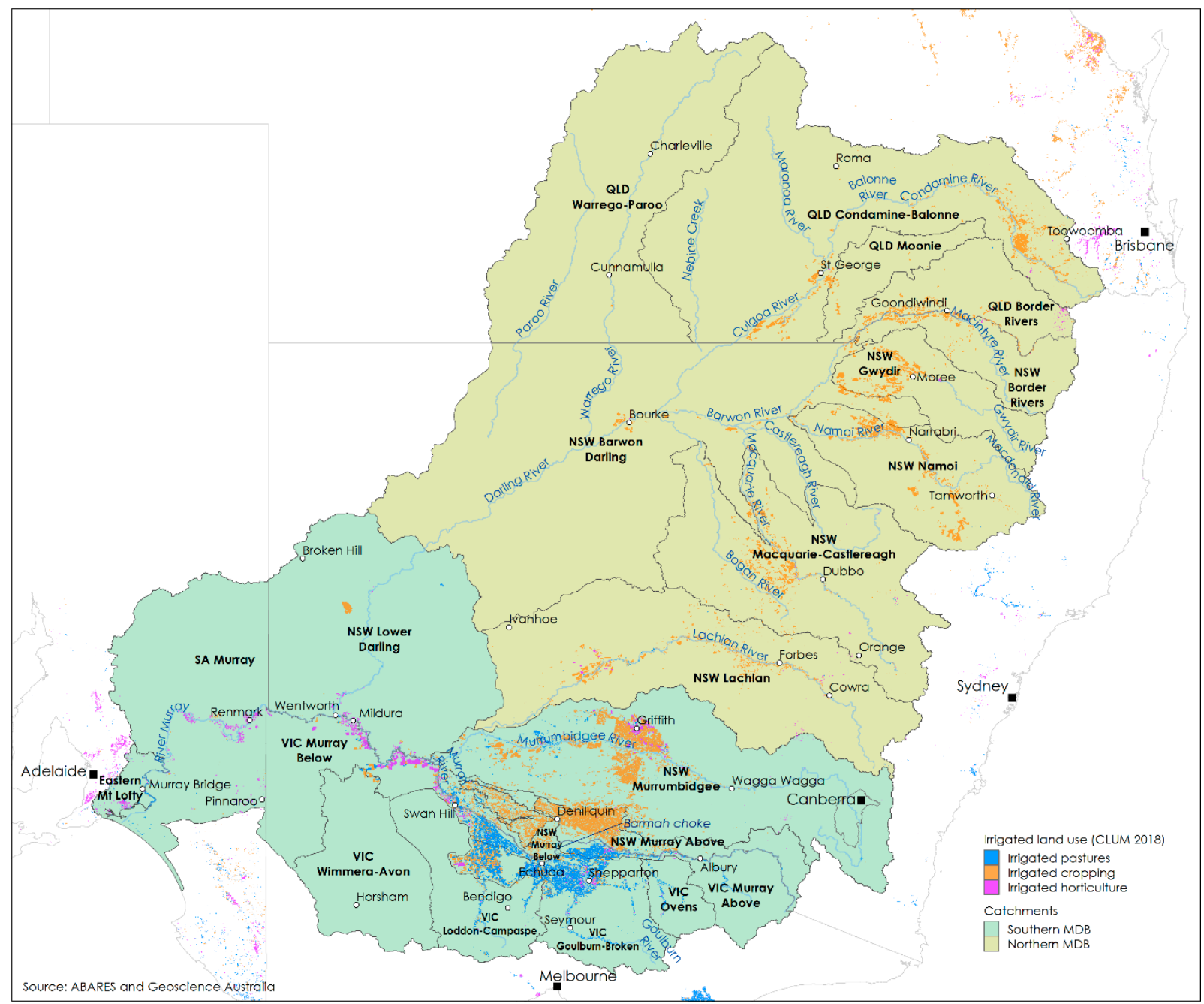

Figure 1. Map of the Murray Darling Basin (MDB) sourced from Goesch et al. 2020 [49].

\subsection{Knowledge Politics—Science Informing Public Policy}

The MDB provides a useful example of how the cultural, political and scientific dimensions of governing a river basin under climate change are interlinked [9]. The extensive literature on the MDB's hydro-climate integrate observations with theoretical and modelling studies $[35,36]$. Climate proxies extend the analysis beyond the instrumental record [50]. Several decades of hydro-climatic research provide a comprehensive yet evolving picture, with a broad consensus emerging about warming and drying trends and their impacts [51].

However, this scientific information is filtered through political and cultural lenses that determine how this advice is applied in policy and practice [9]. There are various conceptual models for how science informs public policy decisions, including by:

1. Providing direct advice to policymakers on climate science $[35,36]$, thereby supporting evidence-based policy [52] by equipping government agencies with scientific knowledge that can meet legislative requirements;

2. Improving public sector decision making through adopting more stringent legally defined procedures [53];

3. Using predictive modelling of climate change impacts [35,54];

4. Contributing to the public's awareness and comprehensions of the need for adaptive policies [55]. 
Several authors raised important questions about how climate science informs policy decisions $[53,54]$. The application of scientific advice in formulating water and climate policy in Australia is neither simple nor straightforward, with constraints to adoption occurring for reasons other than deficiencies in climate change knowledge [50,51,54].

These constraints arise from cultural and political aspects of responding to climate change science that were at play in the MDB, where applying scientific advice to public policy development involved significant tensions [9]. It is necessary to look to the politics of climate knowledge to understand these tensions. The MDB reforms became embroiled in profoundly divisive knowledge politics of climate change. During the reforms, many conservative politicians stridently opposed climate change policies, openly condemning climate science [9]. These positions were supported by well-orchestrated campaigns to undermine decisive change [56]. These campaigns influenced decisions about science-based policy recommendations on water because to change water policies meant the Australian Government needed to openly acknowledge the realities of climate change and, therefore, the need for proactive policy measures for adaptation.

In Australia, as in the USA, divisive politics frame the use of climate science in public policy [57]. Over several decades, mercenaries of doubt exaggerated levels of scientific uncertainty, using tactics refined in campaigns to delay restrictions on tobacco sales [57]. Australia was one of the critical battlegrounds for these campaigns [56]. In the 1980s, Australia had high public awareness of the need for strong policies on climate change, but the confidence needed for strong policy reforms was eroded by well-crafted campaigns [58]. The campaigns were orchestrated and delivered by fossil fuel-funded 'think-tanks' that manufactured doubt, fabricating the uncertainty needed to undermine decisive policies [56]. These campaigns legitimised doubt and emphasised the need for conservative policies by repeatedly calling for greater scientific certainty. Therefore, it is clear that MDB became a battleground in the politics of certainty, with claims about the uncertainty involved in the climate science used to justify minimal changes to estimates about future water resources [9,41]. A reliance on climate science to shape bold reforms in the MDB would have signalled to the Australian public, including many conservative rural voters, that the government accepted the reality of climate change and the need for decisive adaptation policies. These reforms were triggered by a severe decadal drought [13], but widespread flooding occurred before the reform process was completed [9]. Throughout the reform process, debates raged about whether the drought was typical of the Basin's deeply variable climate or partially caused by climate change $[9,10,15]$ (see Figures 2 and 3).

The example of the MDB reforms illustrates that any expectations that science can resolve complex policy dilemmas-through delivering exact answers and absolute truths about future climates-are misguided and unrealistic [59]. Science is not a unified, singular endeavour, because policy agencies' disciplinary linkages accentuate incoherence amongst scientific disciplines during environmental controversies [60]. Water agencies' linkages with the engineering disciplines establish the accepted techniques, standards and procedures for risk management [61,62]. These techniques contrast with the multiple uncertainties and untameable complexities of climate risk assessments, which require conditional, provisional and value-laden or subjective judgments [59]. While the MDBA has statutory responsibilities to use the best available science [8], and to provide scientific information to the public [10], the example demonstrates that scientific advice about climate change and its impacts is always filtered through politically, and therefore, culturally constructed ways of understanding and governing the world $[9,22]$.

\subsection{Climate Adaptation as a Pervasive, Mutating Concept}

The MDB example, outlined above, demonstrates how climate adaptation responses are evolving through the interplay of scientific, political and cultural understanding [6-9]. Climate adaptation is a pervasive and evolving concept, open to multiple framings [63]. At the international level, adaptation concepts are mutating and morphing within debates about disaster risk reduction and geopolitical security [2], often focusing on water, food, 
and energy insecurity [64]. Furthermore, adaptation resources are subject to the predictable competitions for power, influence and legitimacy, which are all about the control of financial resources [65]. While policies, laws, regulations and governance institutions are changing to accommodate changing climatic conditions, outcomes are uncertain [66].

The following section takes these ideas further, looking at how cultures co-construct the climate.

\section{The Cultural Construction of Climate}

\subsection{Introduction}

This section aims to expand on this paper's central idea-that the climate is a socionatural hybrid and that all cultures are in constant processes of negotiation and coconstruction with their climates. Furthermore, these negotiations must accelerate with climate change, as the relatively stable conditions experienced over the past ten thousand years change into a climate that is increasingly unstable. This section outlines how cultures negotiate with the climate, arguing that 'climate normal' and climate change are both culturally constructed. Finally, it sets out that research approaches are needed to develop an integrated understanding of how cultures co-produce the climate.

\subsection{Cultures Negotiate the Climate}

Adjusting to a changing climate involves many complexities, because all socio-natural systems combine their geologies, climates and ecologies with the socio-political, cultural and economic systems [67]. The climates' materiality and sociality are intertwined in people's co-evolutionary dynamics (with their histories, cultures, institutions and technologies) and the places they inhabit and the institutions they develop to govern these relationships [67]. Put another way, societies coevolve with their environments, including the climate, as assemblages of diverse relationships that are continually adjusting to each other and a range of other dynamic factors [68]. The factors involved in these socio-climatic negotiations include a vast array of cultural, technological and natural resource management systems, including adapting to changing seasonal river systems dynamics and utilising the evolutionary characteristics of crop genetics [68]. To understand these co-evolutionary dynamics, we must recognise the deep cultural foundations shaping climate-society relationships [69]. This recognition necessitates ending the false dichotomy between cultural knowledge and the natural sciences and between the social and the natural domains of understanding [69].

Cultural responses to climatic conditions are rich and varied, involving language, stories and histories. They represent countless innovations and adaptations, including building technologies and agricultural systems, plant breeding, and manipulating rivers for irrigation [68]. Adaptation to changing climate also involves countless adjustments in the way people live and work [4] and to policy settings, governance institutions, the law and social norms [7].

\subsection{The Climate as a Powerful Actor in Human Affairs}

The climate remains a powerful actor in human affairs at local, regional, national and international scales. There are multiple feedbacks between climate events, the economy and politics. For example, Birner et al. [70] argued that higher food prices triggered the Arab Spring and global political instabilities in 2008 due to droughts and the rising demand for biofuels. More recently, in Australia, extreme drought conditions led to a range of unprecedented events, including the catastrophic bushfires of the "black summer' of 2020 and 2021 [71]. Extreme climatic events, such as floods, cyclones, droughts and bushfires, create 'crisis conditions' that can result in policy shifts because they challenge societies' capacity to establish and maintain order. These shifts are socio-climatic re-negotiations that redefine accepted institutionalised practices.

Internationally, there are growing concerns about climatic change's impacts on food and water security [64], with predictions of more intense and severe droughts. In south- 
eastern Australia, including the MDB, droughts are defining events, often resetting peoples' lives and public policies [72,73]. Fear of droughts is not new. Primordial fears about climatedriven catastrophes are fundamental to many cultures, which have embedded stories of hardship and survival [73]. Stories of drought's harsh impacts extend from antiquity to the contemporary era [73]. One of humanity's oldest written stories-the Epic of Gilgameshrecounts the adventures of Gilgamesh, the heroic warrior king of Uruk on the Euphrates in Mesopotamia over 4000 years ago. The story goes that Gilgamesh outraged the gods and then slaughtered the Bull of Heaven, bringing seven years of drought and hardship [74]. This epic story is believed to be the origin of the Christian Bible's Old Testament story about seven years of famine and seven years of drought [74]. This story is significant because it portrays the early irrigation city-states adjusting to variable conditions on the Euphrates floodplain [74]. These stories indicate catastrophic changes in ecosystems that accompanied large-scale deforestation and other disruptions resulting from agricultural expansion [74,75].

Responses to episodic drought and floods are central to the ways in which Australia identifies with its climate. Australians identify with the continent as the "land of drought and flooding rain" [76]. Prevailing climatic conditions and culturally conditioned responses frame socialised ideals and imaginaries of the continent and its climate [77]. Australia's recurrent droughts are known as creeping disasters or "slow catastrophes" [73]. They are often the preconditions for significant bushfires such as Ash Wednesday (1983), Black Saturday (2009) and the Black Summer (2020/21) [71]. Droughts and their accompanying bushfires are climatic events that have cultural resonance and political force [72]. They demonstrate the nation's vulnerabilities to climatic forces. For example, the recent Australia drought (2017-2019) was unprecedented in intensity [78]. It led to cascading impacts, including rivers drying up, major fish kills [40] and catastrophic bushfires that intensified the nation's political debates about climate change [55].

Prevailing attitudes to the continent's highly variable climate (see Figure 2) were conditioned by Australia's settler history, with many official documents portraying Australia as a desiccated and deficient and disappointing country that demands heroic 'droughtproofing' [79]. Cathcart [80] traced these attitudes to the shock of colonial settlement, when convicts and marines transplanted from Britain's moist lushness experienced the 'new' country as foreign, dry, disappointing and hostile. This shock catalysed an obsessive "water dreaming", spawning grandiose water schemes and the mythic ideal of conquering the continent's drought and aridity [80]. The colonial project of settlement, occupation and control of the continent institutionalised specific logics and ideals about 'civilising' the 'unworthy' nature of Australia [77,81]. Controlling the rivers to provide irrigation gave the "colonial project" a tangible way of triumphing over a treacherous, unpredictable climate [81] (see Figures 2 and 3).

The contemporary impacts of this domination of the rivers for irrigation supply are significant for the wetlands and riverine ecosystems [10,45]. For Indigenous Peoples, degradation of rivers is deeply disturbing [82,83]. Colonisation resulted in Indigenous Peoples being dispossessed of their land and waterways, disrupting cultural, spiritual and material relationships with rivers [82]. Indigenous communities are deeply concerned by riverine degradation and the way these problems are exacerbated by climate change and neoliberal water reforms [82]. Indigenous People have over 65,000 years of knowledge and experience of Australia's water and waterways, having occupied all the continent's climatic zones [83]. In this long history, they not only adapted to significant climatic changes, including several ice ages, but learnt much that could be of value to contemporary management of water [83]. However, for modern water resource management to be more inclusive of Indigenous knowledge, fundamental changes to policy governance and institutions are required [82,83]. Recognition and inclusion of this knowledge is a cultural challenge for the nation, and its water governance institutions.

The climate is experienced, negotiated and co-produced by individuals and institutions becoming acculturated through various techniques and mechanisms to become ac- 
cepted parts of our daily lives. These include clothing, building and transport technologies, irrigation and agricultural systems and a host of other factors. They also include language, stories, histories, policy settings, and institutionalised attitudes with deep cultural and historical foundations that determine relationships with climatic events like droughts and floods $[73,77,79,80]$. These cultural perspectives and positions become embedded within complex techno-social regimes, reinforced by laws, policies and institutional settings [20,22] that in Australia's case have involved significant Indigenous dispossession [82].

Broadening these cultural foundations to include Indigenous experience and knowledge represents a significant opportunity for reconciliation and social justice in a country wrought by conflict over Indigenous dispossession, environmental degradation and climate policy $[82,83]$. Indigenous perspectives provide a deeper time view on the scope for adaptive adjustments to the changing climate [83]. Opportunities for more reflexive, culturally and environmentally aware and respectful policy settings are highlighted by Indigenous People's insights into how to live in a highly variable and changing climate [83]. While Indigenous People in the MDB have suffered from waves of dispossession, they maintain strong cultural relationships with the rivers and seek to have their rights and responsibilities more formally recognised in reforms to laws and governance institutions $[82,83]$. Such reforms could provide opportunities for legally redefining rivers in ways which respect Indigenous People's deep and significant cultural, material and spiritual relationships. Such reforms need to recognise the ways in which cultural and natural heritage is interwoven in relationships with living rivers.

Creative adjustments and cultural adaptation capabilities are emphasised as necessary as we enter the uncharted conditions emerging after the relatively benign and stable climatic envelope of the Pleistocene. As the Anthropocene conditions destabilise the planetary systems, the ideas of planetary boundaries and a safe operating space for humanity are compelling metaphors that convey the need to attempt to stabilise the climate [23-25]. In structuring our understanding of the climate, the implicit expectation of something close to normal conditions establishes the basis for understanding change. The stable climate is a product of the Pleistocene, and new conceptualisations of the climate, as something more dynamic and dangerous, are emerging in the Anthropocene [1]. These new conceptualisations are changing science, public policy and popular culture in profound ways, embedding an Earth system view to the discussion on managing the planet [84]. This planetary perspective for caution needs to be manifested in local- and bioregional-scale approaches, including those applied at the river catchment or basin scale.

\subsection{The Cultural Construction of Climate-'Climate Normal' and Climate Change}

Preceding sections outlined why we need to recognise the climate's materialities and agency. This section proposes that we must recognise the cultural construction of climate normal and climate change. In addition to being a geophysical phenomenon, climate change is also deeply cultural, in the sense that both climate change and 'climate normal' are culturally constructed. Hulme et al. [2] argued that the whole framing of climate change implies a reference to 'climate normal', itself constructed via a cooperative global scientific effort. This effort involves the measurements and statistical manipulations used to derive the averages that define 'normal' climatic conditions. The notions of the 'climate' embeds these expectations of normality, and therefore, of change from the normal conditions [2]

When we apply the expectation of a standard or predictable climate, the deviations from normal conditions are referred to as extreme events and 'anomalies', implying the abnormality of non-average conditions (see Figure 2). However, in southern Australia, conditions conforming to the "average" conditions occur coincidentally due to fundamental drivers of the oceans' climatic conditions that bring oscillating wet-dry cycles [15,61]. Reconstructions of the hydro-climate beyond the instrumental records, using climate proxies, demonstrate that recurrent droughts, punctuated by floods, typify the climate patterns over centuries and millennia [85]. Furthermore, these proxy records indicate that 
extreme flood events and long periods of drought are distinct and typical parts of the historical record [85].

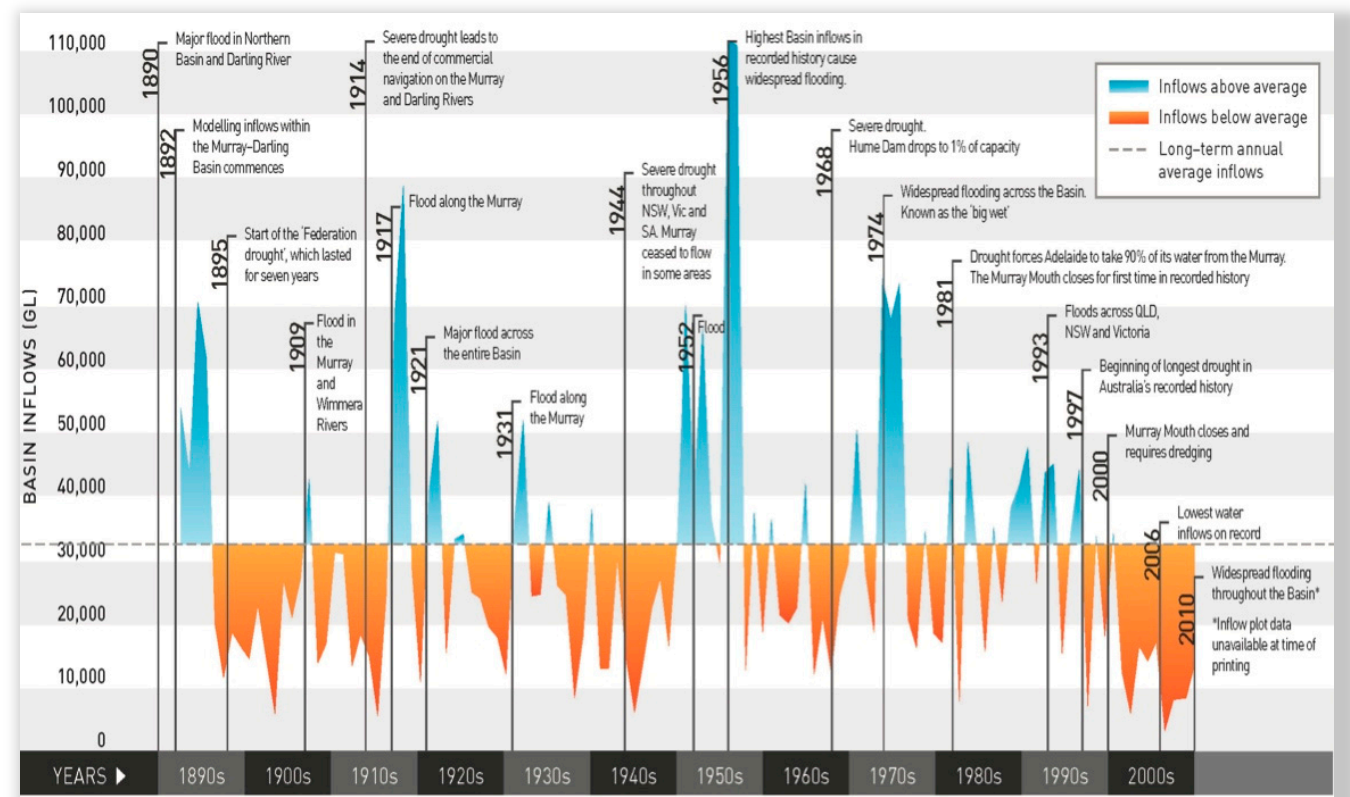

Figure 2. River inflows for the Murray Darling Basin [86].
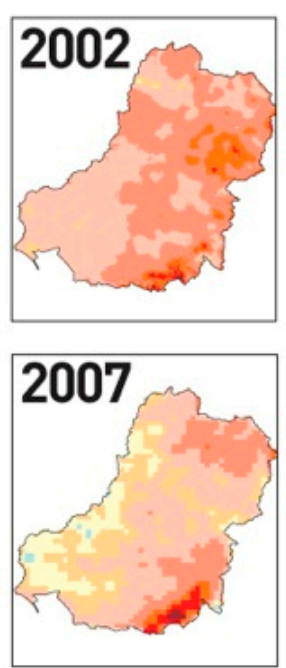
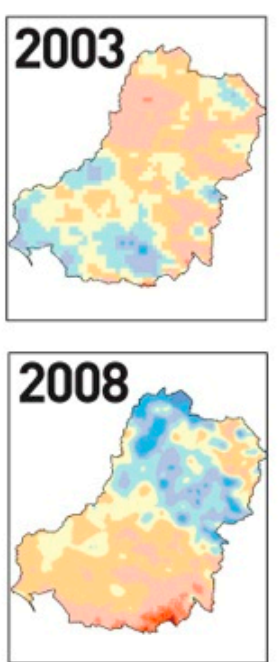
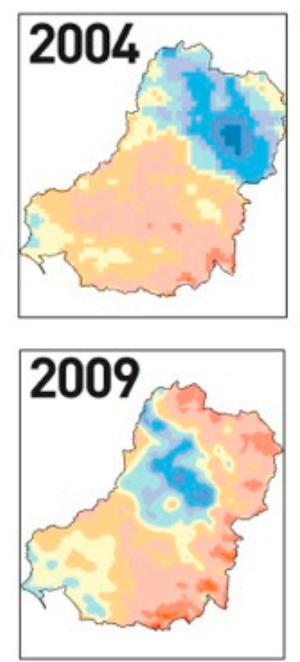
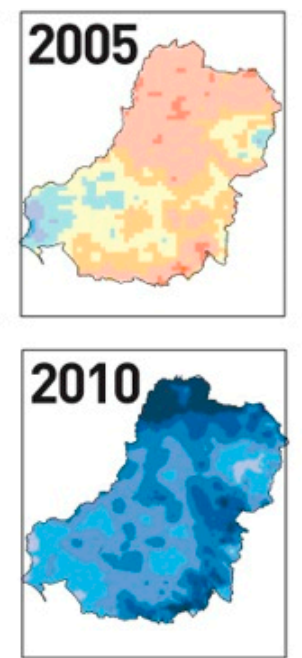
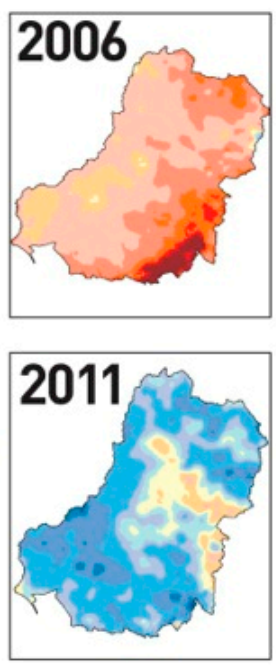

Annual rainfall anomaly 2001-2010 (mm)

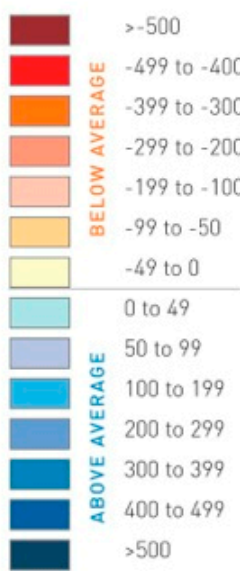

Figure 3. Rainfall “anomalies" 2002 to 2011 in the MDB [87].

Policy 'artefacts' - posters, brochures, websites and reports intended to inform, educate and instruct 'the public' - offer potential sources for research exploring the cultural construction of climate and how official documents represent climatic conditions [79,80]. For example, the MDBA's [86,87] (2011a and 2011b) posters on river inflows (Figure 2) and the Millennium Drought's rainfall anomalies (Figure 3) reveal ways the cultural construction of 'climate normal' are reinforced and refracted by countless representations of nature [3]. With their references to averages and deviations from them, these posters offer evidence that averages conditions are abnormal due to the climate oscillating through extended cycles of drought-flood $[15,61,85]$. These representations of the climate demonstrate how concepts of 'climate normal' are reinforced through posters and other information 
sources and used to justify policies that attempt to drought-proof irrigated agriculture in the basin $[77,79]$.

The two posters reproduced above are examples of the abundance of information that conditions our comprehension of the climate. These representations embed concepts of nature and its averaged conditions [3], and that define variations or changes arising in contrast to these averages. Averages are not just used to represent the climate, but are also the basis of water resource planning in the MDB, where averages of available water resources were projected forward to 2030 by the statutory instrument of the Basin Plan, despite strong scientific evidence of a drying climate [8-10].

The Millennium Drought (1996-2010) had severe impacts on riverine ecosystems, industries and communities throughout the Basin [15]. The drought was defined as a national crisis that triggered major reforms [15]. However, while there is much evidence for climate change contributing to the drying of the MDB, the MDBA relied on the 114-year climate history (1895-2009) for the Basin Plan modelling [8]. Therefore, the MDB Plan relies on the historical climate during the instrumental period, as the basis for future projections. This failure to adequately incorporate climate science into responses to climate risks has been described by a formal judicial inquiry as incomprehensible maladministration [9]. However, this choice may also indicate a deep-seated yearning from settler-colonial water governance institutions for a safe, reliable, 'normal' climate, one that delivers predictable water supplies to the intensively irrigated agriculture that has arisen in the Basin in a little over a century of re-engineering the rivers for that purpose.

In contrast to irrigated agriculture, the ecosystems of the MDB have evolved to be superbly adapted to the boom-bust, flood-drought cycles driven by the southern continent's highly variable climate [15,61] (see also Figures 2 and 3). However, these ecosystems cannot adjust to the impacts of over extraction of water for irrigation [40,45]. A deep reluctance to accept the flood-drought cycle is apparent in the history of Australia's policies [11,12], many of which focused on drought proofing-ambitious engineering schemes intended to overcome the continent's variability [77,79,81]. A similar type of reluctance to accept the reality of climate change is driving maladaptive policy formulation, including an unattainable search for scientific certainty, and the conflation of climate variability with climate change in many official documents [9].

By bringing a cultural perspective to interpreting the MDB reforms, this paper argues that the hydro-climatic conditions of the Basin are coproduced by culture. These variable conditions are a combination of the natural or physical phenomena, and the way water and rivers are defined, understood and governed. Settler-colonial Australia has increasingly defined water as an extractable resource that can be exchanged in a market economy, to the detriment of a range of other aspects of the value of rivers [40,82]. To protect these other aspects of value and to become genuinely inclusive of Indigenous People's perspectives and relationships will require significant renegotiations on the fundamentals principles and practices of how water is understood and governed in modern Australia $[82,83,88,89]$. Developing models of co-governance and recognising Indigenous wisdom, experience and connections provides important opportunities for recalibrating the nation's relationships to its rivers $[83,88,89]$. As a nation, Australia can only do this through integrating natural and cultural heritage conservation, developing appropriate models of economic development and recognising the long and proud history of Indigenous governance of rivers and their catchments $[88,89]$. Incorporating long-term cultural perspectives provides significant opportunities for treating rivers, and their peoples, with greater respect and reverence $[88,89]$.

\section{Conclusions-The Climate Is a Socio-Natural Hybrid}

This paper has profiled some of the cultural dimensions of understanding how climate was handled in recent MDB reforms, arguing that our understanding and experience of the climate is culturally conditioned. An understanding of the climate involves the intersection of subjective and objective truths, the local and global scales, and the personal 
and political. Our experience of climatic events is an experience of the massive dynamics of the atmosphere's and the oceans' global circulation patterns. However, the climate is also profoundly social in its impacts, representation and comprehension, and therefore, it is comprehended and filtered through cultural and historical lenses [1-3]. These cultural dimensions contribute to meaning making in relation to the climate.

Even the ubiquitous weather forecasts are the result of networks of relationships between people and technologies—satellites, computers, models, gadgets, forecasters, and laboratories track, monitor, and predict weather events and patterns [2]. These networks are continuously gauging and representing atmospheric phenomena - rain, hail, winds and clear skies. For example, these relational networks bring distracting images of the weather system to my computer, as the southern ocean storms bring bands of rain drumming down on the steel roof while I am writing about climate science and contemplating the filling and draining of rivers and the larger patterns of droughts and floods. This small account illustrates that our personal experience, knowledge and technologies mediate the understanding of weather events, repeatedly generating and reinforcing concepts about the climate. This mediation includes various theories, abstractions and collective instrumentation and statistical assembling of the climate and what it means for our lives, and collective decisions about how to live on this planet $[1,2,7]$.

This paper argues that the climate is a hybrid between the social and natural, the technological and cultural [7]. However, this hybrid and these relationships are not just the product of modern information technology and Earth systems monitoring. In Australia, cultural relationships with water, rivers and the climate have a long-enduring lineage, which needs to be recognised in modern governance institutions [82,83,88,89]. Such recognition could guide a profound reset in how water is governed and how the challenges of climate adaptation are understood.

Recognising the climate as a socio-natural hybrid has profound implications for climate research and policy. According to Latour [5], socio-natural hybrids are coproduced from the marriage of the social and natural worlds. Rivers and the climate are a socionatural hybrid, neither entirely natural nor fully social, something constructed, created from the relationship between these two realms [7]. Furthermore, it needs to be acknowledged that the natural sciences institutions that attempt to understand these hybrids through positivist pursuits of objectives truths have their own rituals and cultures [5]. However, more importantly, cultural perspectives help to reveal that the scientific truths generated about the world contribute to the construction of meaning that underpins ethical dimensions of the trajectories of politics and the law $[6,7]$. These ethical dimensions include questions about how we individually and collectively respond to the climate emergencies [7]. Latour [5] argues that nature is no longer merely a backdrop for the human story, but a central actor in the drama. The Anthropocene's emerging realities and intricate connections are blurring the distinctions between the human and the natural, meaning that every action has moral and environmental dimensions in terms of governing the Earth system [84]. However, in practice, the Earth is governed in hundreds of countries and millions of localities. This governing relies on ethical and normative frameworks that frame and steer how we live. The integration of social, spiritual and environmental responsibilities is in accordance with many traditional governance systems that evolved in Australia, which recognise many deep, complex and concurrent relationships between people, rivers, the land, the plants and animals and the spiritual world [88,89].

A repositioning of human-nature relationships shifts many of the fundamentals of how we undertake research and divide the sciences into their respective categories of the 'social' and the 'natural' sciences. Research suitable for the Anthropocene $[6,16,84]$ requires theoretical frameworks and methods suitable for the integrated interpretation of how climates, cultures and their governing systems coevolve within their territorial, political, cultural and historical contexts. Critical realism's (CR) realist ontology and interpretive epistemology provide a framework that enables inquiry into the interplay between the changing climate and socio-political change. $\mathrm{CR}$ recognises an independent reality, is atten- 
tive to real-world materialities and sees all knowledge mediated via cultural constructs [19]. $\mathrm{CR}$ is, therefore, suitable for interdisciplinary research on complex sustainability issues that involve the interrelationships between natural and cultural systems and the integration of natural and social sciences $[20,21]$. CR offers a philosophy of knowledge useful for the integrated studies needed for studies into climate adjustments.

Bringing a culturally informed perspective to understanding the climate will enable more diverse ways of responding to climate change. Recognising the diversity of cultural positions and perspectives inherent in our understanding of the climate, and how these manifest in specific places or systems, such as river basins, will help to support more reflexive research and policy practices. Investigating appropriate responses to a more dynamic and unpredictable Earth system, whether at local, national or river basin scales, will inevitably have many practical, theoretical cultural and philosophical challenges. Ways to meaningfully overcome these challenges are worthy subjects of further scholarship.

Author Contributions: This is a sole author paper. Conceptualization J.A.; methodology, J.A.; investigation, J.A.; writing—original draft preparation, J.A.; writing—review and editing, J.A.; and project administration, J.A. The author has read and agreed to the published version of the manuscript.

Funding: This research received no external funding.

Acknowledgments: Sincere thanks to those who have provided valuable guidance on this research, including reviewers, who improved earlier versions. Figures attributed to Australian Government agencies of ABARE, CSIRO, and MDBA are provided under a Creative Commons Attribution 4.0 licence.

Conflicts of Interest: The authors declare no conflict of interest.

\section{References}

1. Hulme, M. The conquering of climate: Discourses of fear and their dissolution. Geogr. J. 2008, 174, 5-16. [CrossRef]

2. Hulme, M.; Dessai, S.; Lorenzoni, I.; Donald, R.; Nelson, D.R. Unstable climates: Exploring the statistical and social constructions of 'normal' climate. Geoforum 2008, 40, 197-206. [CrossRef]

3. Castree, N. Making Sense of Nature; Routledge: Oxford, UK, 2014.

4. Cunningham, R.; Jacobs, B.; Measham, T.G. Uncovering Engagement Networks for Adaptation in Three Regional Communities: Empirical Examples from New South Wales, Australia. Climate 2021, 9, 21. [CrossRef]

5. Latour, B. We Have Never Been Modern; Harvard University Press: Cambridge, MA, USA, 1993.

6. Ison, R.; Alexandra, J.; Wallis, P. Governing in the Anthropocene: Are there cyber-systemic antidotes to the malaise of modern governance? Sustain. Sci. 2018, 13, 1209-1223. [CrossRef]

7. Latour, B. Down to Earth: Politics in the New Climatic Regime; Polity: Cambridge, UK, 2018.

8. Alexandra, J. Navigating the Anthropocene's rivers of risk-climatic change and science-policy dilemmas in Australia's MurrayDarling Basin. Clim. Chang. 2021, 165, 1-21. [CrossRef]

9. Alexandra, J. The science and politics of climate risk assessment in Australia's Murray Darling Basin. Env. Sci. Policy 2020, 112, 17-27. [CrossRef]

10. Alexandra, J. Evolving Governance and Contested Water Reforms in Australia's Murray Darling Basin. Water 2018, 10, 113. [CrossRef]

11. Heathcote, R.L. Drought in Australia: A Problem of Perception. Geogr. Rev. 1969, 59, 175. [CrossRef]

12. Heathcote, R.L. Drought in Australia: Still a problem of perception? Geo J. 1988, 16, 387-397. [CrossRef]

13. Horne, J. Water policy responses to drought in the MDB, Australia. Water Policy 2016, 18, 28-51. [CrossRef]

14. Howden, M.; Schroeter, S.; Crimp, S.; Hanigan, I. The changing roles of science in managing Australian droughts: An agricultural perspective. Weather Clim. Extrem. 2014, 3, 80-89. [CrossRef]

15. Van Dijk, A.I.J.M.; Beck, H.E.; Crosbie, R.S.; de Jeu, R.A.M.; Liu, Y.Y.; Podger, G.M.; Timbal, B.; Viney, N.R. The Millennium Drought in southeast Australia (2001-2009): Natural and human causes and implications for water resources, ecosystems, economy, and society. Water Resour. Res. 2013, 49. [CrossRef]

16. Dankel, D.J.; Vaage, N.S.; van der Sluijs, J.P. Post-normal science in practice. Futures 2017, 91, 1-4. [CrossRef]

17. Sylla, M.B.; Faye, A.; Klutse, N.A.B.; Dimobe, K. Projected increased risk of water deficit over major West African river basins under future climates. Clim. Chang. 2018, 151, 247-258. [CrossRef]

18. Danermark, B.; Ekstrom, M.; Jakobsen, L.; Karlsson, J.C. Explaining Society: Critical Realism in the Social Sciences; Routledge: London, UK, 2002.

19. Wynn, D.E., Jr.; Williams, C.K. Recent Advances and Opportunities for Improving Critical Realism-Based Case Study Research in IS. J. Assoc. Inf. Syst. 2020, 21, 8. Available online: https://aisel.aisnet.org/jais/vol21/iss1/8 (accessed on 17 October 2020). [CrossRef] 
20. Mollinga, P. Knowledge, context and problem sheds: A critical realist method for interdisciplinary water studies. Water Int. 2020, 45, 388-415. [CrossRef]

21. Nastar, M.; Boda, C.S.; Olsson, L. A critical realist inquiry in conducting interdisciplinary research: An analysis of LUCID examples. Ecol. Soc. 2018, 23, 41. [CrossRef]

22. Mollinga, P.P. Cultural Political Economy and critical water studies: An introduction to the special themed section. Water Altern. 2019, 12, 788-801.

23. Steffen, W.; Crutzen, P.J.; McNeill, J.R. The Anthropocene: Are Humans Now Overwhelming the Great Forces of Nature. Ambio A J. Hum. Environ. 2007, 36, 614-621. [CrossRef]

24. Steffen, W.; Richardson, K.; Rockström, J.; Schellnhuber, H.J.; Dube, O.P.; Dutreuil, S.; Lenton, T.M.; Lubchenco, J. The emergence and evolution of Earth System Science. Nat. Rev. Earth Environ. 2020, 1, 54-63. [CrossRef]

25. Rockström, J.; Steffen, W.; Noone, K.; Persson, Å.; Chapin, F.S.; Lambin, E.F.; Lenton, T.M.; Scheffer, M.; Folke, C.; Schellnhuber, H.J.; et al. A safe operating space for humanity. Nature 2009, 461, 472-475. [CrossRef]

26. Palmer, M.A.; Reidy Liermann, C.A.; Nilsson, C.; Flörke, M.; Alcamo, J.; Lake, P.S.; Bond, N. Climate change and the world's river basins: Anticipating management options. Front. Ecol. Environ. 2008, 6, 81-89. [CrossRef]

27. Pahl-Wostl, C. Governance of the water-energy-food security nexus: A multi-level coordination challenge. Environ. Sci. Policy 2017, 92, 356-367. [CrossRef]

28. IPCC. Summary for Policymakers. In Global Warming of $1.5^{\circ} \mathrm{C}$; Masson-Delmotte, V., Zhai, P., Pörtner, H.-O., Roberts, D., Skea, J., Shukla, P.R., Pirani, A., Moufouma-Okia, W., Péan, C., Pidcock, R., et al., Eds.; 2018; Available online: https:/ / www.ipcc.ch/site/ assets/uploads/sites/2/2019/05/SR15_SPM_version_report_LR.pdf (accessed on 30 December 2020).

29. Trenberth, K.E. Changes in precipitation with climate change. Clim. Res. 2011, 47, 123-138. [CrossRef]

30. Xu, J.; Grumbine, R.E.; Shrestha, A.; Eriksson, M.; Yang, X.; Wang, Y.U.N.; Wilkes, A. The melting Himalayas: Cascading effects of climate change on water, biodiversity, and livelihoods. Conserv. Biol. 2009, 23, 520-530. [CrossRef]

31. Gleick, P.H. Regional hydrologic consequences of increases in atmospheric $\mathrm{CO}_{2}$ and other trace gases. Clim. Chang. 1987, 10, 137-160. [CrossRef]

32. Riebsame, W.E. Adjusting water resources management to climate change. Clim. Chang. 1988, 13, 69-97. [CrossRef]

33. Milly, P.C.; Betancourt, J.; Falkenmark, M.; Hirsch, R.M.; Kundzewicz, Z.W.; Lettenmaier, D.P.; Stouffer, R.J. Climate Change: Stationarity Is Dead: Whither Water Management? Science 2008, 319, 573-574. [CrossRef]

34. CSIRO. Water Availability in the Murray-Darling Basin-CSIRO Murray-Darling Basin Sustainable Yields Project CSIRO 2008. Available online: https:/ / publications.csiro.au/rpr/download?pid=legacy:530\&dsid=DS1 (accessed on 12 December 2019).

35. CSIRO. Climate Change and Variability in SE Australia-A Synthesis of Phase 1 of SEACI; CSIRO: Canberra, Australia, 2010.

36. CSIRO. SEACI Phase 2 Synthesis Report, Climate and Water Availability in South-Eastern Australia. 2012. Available online: http: //www.seaci.org/publications/documents/SEACI-2Reports/SEACI_Phase2_SynthesisReport.pdf (accessed on 12 December 2019).

37. CSIRO. State of the Climate 2020. 2020. Available online: https:/ /www.csiro.au/en/Showcase/state-of-the-climate (accessed on 12 December 2020).

38. Steffen, W.; Vertessy, R.; Dean, A.; Hughes, L.; Bambrick, H.; Gergis, J.; Rice, M. Deluge and Drought: Australia's Water Security in a Changing Climate; Climate Council of Australia Ltd.: Sydney, Australia, 2018.

39. Whetton, P.H.; Grose, M.R.; Hennessy, K.J. A short history of the future: Australian climate projections 1987-2015. Clim. Serv. 2016, 2, 1-14. [CrossRef]

40. Jackson, S.; Head, L. Australia's mass fish kills as a crisis of modern water: Understanding hydrological change in the MurrayDarling Basin. Geoforum 2020, 109, 44-56. [CrossRef]

41. Alexandra, J. Risks, Uncertainty and Climate Confusion in the Murray-Darling Basin Reforms. Water Econ. Policy 2017, 3, 1650038-21. [CrossRef]

42. Donohue, R.J.; Roderick, M.L.; McVicar, T.R. Assessing the differences in sensitivities of runoff to changes in climatic conditions across a large basin. J. Hydrol. 2011, 406, 234-244. [CrossRef]

43. Donohue, R.J.; Roderick, M.L.; McVicar, T.R.; Farquhar, G.D. Impact of $\mathrm{CO}_{2}$ fertilisation on maximum foliage cover across the globe's warm, arid environments'. Geophys. Res. Lett. 2013, 40, 3031-3035. [CrossRef]

44. Roderick, M.; Farquhar, G. A simple framework for relating variations in runoff to variations in climatic conditions and catchment properties. Water Resour. Res. 2011, 47, W00G07-11. [CrossRef]

45. Pittock, J.; Finlayson, C.M. Australia's Murray-Darling Basin: Freshwater ecosystem conservation options in an era of climate change. Mar. Freshw. Res. 2011, 62, 232-243. [CrossRef]

46. Alexandra, J.; Finlayson, M.C. Floods after bushfires: Rapid responses for reducing impacts of sediment, ash, and nutrient slugs. Australas. J. Water Resour. 2020, 24, 9-11. [CrossRef]

47. Wheeler, S.A.; Xu, Y.; Zuo, A. Modelling the climate, water and socio-economic drivers of farmer exit in the Murray-Darling Basin. Clim. Chang. 2020, 158, 551-574. [CrossRef]

48. Grafton, R.Q.; Williams, J. Rent-seeking behaviour and regulatory capture in the Murray-Darling Basin, Australia. Int. J. Water Resour. Dev. 2019, 36, 484-504. [CrossRef]

49. Goesch, T.; Legg, P.; Donoghoe, M. Murray-Darling Basin Water Markets: Trends and Drivers 2002-03 to 2018-19; ABARES Research Report; ABARES: Canberra, Australia, 2020. 
50. Tozer, C.R.; Vance, T.R.; Roberts, J.; Kiem, A.S.; Curran, M.A.J.; Moy, A.D. An ice core derived 1013-year catchment scale annual rainfall reconstruction in subtropical eastern Australia. Hydrol. Earth Syst. Sci. 2016, 20, 1703-1717. [CrossRef]

51. Whetton, P.; Chiew, F. Climate change in the Murray-Darling Basin. In Ecohydrology from Catchment to Coast, Murray-Darling Basin, Australia; Hart, B.T., Bond, N.R., Byron, N., Pollino, C.A., Stewardson, M.J., Eds.; Elsevier: Amsterdam, The Netherlands, 2021; Volume 1, pp. 253-274. [CrossRef]

52. Oliver, K.; Boaz, A. Transforming evidence for policy and practice: Creating space for new conversations. Palgrave Commun. 2019, 5, 60. [CrossRef]

53. O'Donnell, E.; Nelson, R. Shield science for robust decisions. Nat. Sustain. 2020, 3, 675-676. [CrossRef]

54. Hatton, T.; Young, W. Delivering Science into Public Policy: An Analysis of Murray-Darling Basin Sustainable Yields Assessment as a Model for Impact. Aust. J. Public Adm. 2011, 70, 298-308. [CrossRef]

55. Mocatta, G.; Hawley, E. Uncovering a Climate Catastrophe? Media Coverage of Australia's Black Summer Bushfires and the Revelatory Extent of the Climate Blame Frame. M/C J. 2020, 23. [CrossRef]

56. Wilkinson, M. The Carbon Club: How a Network of Influential Climate Sceptics Politicians and Business Leaders Fought to Control Australia's Climate Policy; Allen and Unwin: Sydney, Australia, 2020.

57. Oreskes, N.; Conway, E.M. Defeating the merchants of doubt. Nature 2010, 465, 686-687. [CrossRef]

58. Taylor, M. Global Warming and Climate Change What Australia Knew and Buried ... Then Framed a New Reality for the Public; ANU Press: Canberra, Australia, 2014. Available online: https://pressfiles.anu.edu.au/downloads/press/p303951/pdf/book.pdf (accessed on 22 December 2020).

59. Dessai, S.; Hulme, M. Does climate adaptation policy need probabilities? Clim. Policy 2004, 4, 107-128. [CrossRef]

60. Sarewitz, D. How science makes environmental controversies worse. Environ. Sci. Policy 2004, 7, 385-403. [CrossRef]

61. Kiem, A.S.; Verdon-Kidd, D.C. The importance of understanding drivers of hydroclimatic variability for robust flood risk planning in the coastal zone. Australas. J. Water Resour. 2013, 17, 126-134. [CrossRef]

62. Lane, S.N. Acting, predicting and intervening in a socio-hydrological world. Hydrol. Earth Syst. Sci. 2014, 18, 927-952. [CrossRef]

63. Head, L. Cultural ecology: Adaptation-retrofitting a concept? Prog. Hum. Geogr. 2010, 34, 234-242. [CrossRef]

64. Allouche, J.; Middleton, C.; Gyawali, D. The Water-Food-Energy Nexus: Power, Politics, and Justice; Routledge: Abingdon, UK, 2019.

65. Nightingale, A. Power and politics in climate change adaptation efforts: Struggles over authority and recognition in the context of political instability. Geoforum 2017, 84, 11-20. [CrossRef]

66. Cosens, B.A.; Gunderson, L.; Chaffin, B. Practicing Panarchy: Assessing legal flexibility, ecological resilience, and adaptive governance in regional water systems experiencing rapid environmental change. Ecol. Soc. 2018, 23, 4. [CrossRef]

67. Dittmer, J. Geopolitical assemblages and complexity. Prog. Hum. Geogr. 2013, 38, 385-401. [CrossRef]

68. Biggs, D. 2014 Promiscuous Transmission and Encapsulated Knowledge: A Material-Semiotic Approach to Modern Rice in the Mekong Delta. In Rice: Global Networks and New Histories; Bray, F., Coclanis, P., Fields-Black, E., Schäfer, D., Eds.; Cambridge University Press: Cambridge, UK, 2014; pp. 118-137.

69. Descola, P. Beyond Nature and Culture; English Edition; University of Chicago Press: Chicago, IL, USA, 2012.

70. Birner, R.; Davis, K.; Pender, J.; Nkonya, E.; Anandajayasekeram, P.; Ekboir, J.; Mbabu, A.; Spielman, D.J.; Horna, D.; Benin, S.; et al. From Best Practice to Best Fit: A Framework for Designing and Analysing Pluralistic Agricultural Advisory Services Worldwide. J. Agric. Educ. Ext. 2009, 15, 341-355. [CrossRef]

71. Norman, B.; Newman, P.; Steffen, W. Apocalypse now: Australian bushfires and the future of urban settlements. Jnp. Urban Sustain. 2021, 1, 2. [CrossRef]

72. Head, L.; Gibson, C. Becoming differently modern Geographic contributions to a generative climate politics. Prog. Hum. Geogr. 2012, 36, 699-714. [CrossRef]

73. Jones, R. Slow Catastrophes_Living with Drought in Australia; Monash University Publishing: Melbourne, Australia, 2017.

74. Sandars, N.K. The Epic of Gilgamesh; Penguin Books: Melbourne, Australia, 1972.

75. Scheffer, M.; Carpenter, S.R.; Jonathan, A.; Foley, J.A.; Folke, C.; Walker, B. Catastrophic shifts in ecosystems. Nature 2001, 413, 591-596. [CrossRef]

76. Mackellar, D. Core of My Heart, London Spectator. 1908. Available online: www.sl.nsw.gov.au/stories/my-country-dorotheamackellar (accessed on 3 November 2017).

77. Gibbs, L. Just add water: Colonisation, water governance, and the Australian inland. Environ. Plan. A 2009, 41, 2964-2983. [CrossRef]

78. BOM. Climate Change Tracker. 2020. Available online: http://www.bom.gov.au/climate/change/index.shtml\#tabs=Tracker\& tracker=timeseries\&tQ=graph\%3Dtmean\%26area\%3Dmdb\%26season\%3D0112\%26ave_yr\%3D0 (accessed on 18 January 2020).

79. Arthur, J.M. The Default Country: A Lexical Cartography of Twentieth-Century Australia; UNSW Press: Sydney, Australia, 2003.

80. Cathcart, M. The Water Dreamers - The Remarkable History of Our Dry Continent; Text: Melbourne, Australia, 2009.

81. Lines, J. Taming the Great South Land: A History of the Conquest of Nature in Australia; Penguin: Melbourne, Australia, 1994.

82. Hartwig, L.; Jackson, S.; Osborne, N. Trends in Aboriginal water ownership in New South Wales, Australia: The continuities between colonial and neoliberal forms of dispossession. Land Use Policy 2020. [CrossRef]

83. Moggridge, B.J.; Thompson, R.M. Cultural value of water and western water management: An Australian indigenous perspective. Australas. J. Water Resour. 2021. [CrossRef]

84. Castree, N. Framing, deframing and reframing the Anthropocene. Ambio 2021. [CrossRef] 
85. Gallant, A.J.E.; Gergis, J. An experimental streamflow reconstruction for the River Murray, Australia, 1783-1988. Water Resour. Res. 2011, 47, W00G04. [CrossRef]

86. MDBA. Annual Rainfall Anomalies 2002 to 2011; MDBA: Canberra, Australia, 2011.

87. MDBA. Basin inflows 1892-2010; MDBA: Canberra, Australia, 2011.

88. River of Life; Martuwarra; Poelina, A.; Alexandra, J.; Samnakay, N. A conservation and management plan for the National Heritage listed Fitzroy River Catchment Estate (No. 1). Martuwarra Fitzroy River Council, Nulungu Research Institute. Univ. Notre Dame Aust. 2020. [CrossRef]

89. Poelina, A.; Taylor, K.S.; Perdrisat, I. Martuwarra Fitzroy River Council: An Indigenous cultural approach to collaborative water governance. Australas. J. Env. Manag. 2019, 26, 236-254. [CrossRef] 